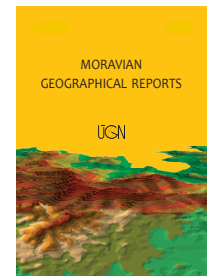

MORAVIAN GEOGRAPHICAL REPORTS

\title{
Analysis of the development of land use in the Morava River floodplain, with special emphasis on the landscape matrix
}

\author{
Helena KILIANOVÁ a *, Vilém PECHANEC ${ }^{\text {a }}$, Jan BRUS ${ }^{\text {a }}$, Karel KIRCHNER ${ }^{\text {b }}$, Ivo MACHAR ${ }^{\mathrm{c}}$
}

\begin{abstract}
The results of an analysis of land use development in the Morava River floodplain (Czech Republic) using GIS from 1836 to the present, are the subject of this article. The results are based on the analysis of historical maps, using the landscape matrix assessment of the Morava River floodplain. The final analyses were processed from land use maps of the floodplain at a scale of $1: 25,000$ in five time horizons. These maps were compared with the present state of landscape by GIS methods. The study area was assessed according to five geomorphological areas from the northern/higher part to the southern/lower part of floodplain. In 1836 the landscape matrix of the floodplain was composed of meadows and forests. Forest components decreased minimally but the changes are more important. The grassland area (meadows and pastures) decreased but arable land, as well as settlements, increased very significantly. In the 1950s the landscape matrix was composed of a mosaic of alluvial forests, meadows and arable land. Currently, the predominant landscape matrix consists of arable land and isolated forest complexes.
\end{abstract}

Keywords: historical maps, land use changes, floodplain, GIS, Morava River, Czech Republic

Article history: Received 8 March 2016; Accepted 15 February 2017; Published 31 March 2017

\section{Introduction}

Issues of land use in the floodplains of large rivers are a permanent subject of geographic research since these areas have considerable economic and ecological importance and were affected by human activities in the course of historical development. Land use includes those human activities that affect the spatial dimensions and which causes changes in the geo-ecological conditions of land. Studying the dynamics of development and land use change is important with respect to management planning, as well as for ecosystem services in floodplain areas. This paper focuses on landscape changes in specific floodplain areas of the Morava River in the Czech Republic (CR). This research project is based on an interpretation of historical maps compared with contemporary maps, using methods based on geographical information systems (GIS).

\section{Theoretical background}

The landscape matrix is the dominant background land use/land cover type of a landscape. Applications of the concept of the landscape matrix (Forman and Godron, 1986) were developed as the patch matrix model (PMM) in the 1980s in order to quantify landscape structure (McGarigal et al., 2009). The PMM can be considered as one of the first conceptual models for landscape structure (Farina and Belgrano, 2006). Because the PMM has compatibility with data models in GIS, landscape structure based on the PMM is useful as an indicator of biodiversity (Dauber et al., 2003). The quantification of spatial and compositional aspects of PMM promoted the developments of numerous landscape indicators (Gergel, 2004), which can be applied in conservation practice, e.g. in nature reserve design (Clark and Slusher, 2000).

Landscape changes under PMM are influenced by natural conditions and socioeconomic factors. Many authors have assessed the influence of environmental drivers on landscape changes or structure and their analysis of driving forces of land use (Druga and Faltan, 2014; Havlíček et al., 2014; Machar, 2012a). Opršal et al. (2016) analysed changes in landscape use and the related significance of some natural factors using three municipal cadastral areas in Moravia, CR. Environmental and socioeconomic drivers have been

\footnotetext{
${ }^{a}$ Department of Geoinformatics, Faculty of Science, Palacký University Olomouc, Czech Republic (*corresponding author: H. Kilianová, e-mail: helena.kilianova@upol.cz)

${ }^{\mathrm{b}}$ Dept. of Environmental Geography, Institute of Geonics, The Czech Academy of Sciences, Brno, Czech Republic

${ }^{\mathrm{c}}$ Dept. of Development and Environmental Studies, Faculty of Science, Palacký University Olomouc, Czech Republic
} 
associated with PMM: for example, in a study of marginal agricultural landscapes in Portugal (Van Doorn and Bakker, 2007), and a study of farmland abandonment in eastern China (Wu and Zhang, 2012). A study of a Swedish agricultural landscape (Gustavsson et al., 2007) shows how changes in management from mowing to grazing a century ago may cause diversity declines similar to abandonment that occurred 40 years ago. In this context, Benjamin et al. (2005) notes that changes in intensity of land-use contribute to a large range of habitat modifications, plant community fragmentation and changes in landscape structure.

Geoinformation technology (GIT) encompasses the modern processing of spatial data and support of PMM by means of information technology. The rapidly evolving information society sees GIT becoming an integral part of many fields of human activities, among them science subjects, which study spatial distribution of various phenomena, their characteristics and relations. GIT has applications primarily in geographic information systems, remote sensing, global positioning systems and computer cartography (Tomlinson, 2003; Longley et al., 2010).

A geographic information system (GIS) allows for the collection, processing and management of geographic data related to natural and human resources, aids deeper understanding of the field, yields more accurate information, is capable of a high-precision representation of reality in a computer environment, and makes decisionmaking processes easier (Al-Adamat et al., 2010; Pechanec et al., 2015). It also allows its users to model a number of natural processes, thus facilitating the planning of the utilisation and predictions of natural resources management development (Kubíček et al., 2011).

The Czech Republic has a sufficient amount of data sources representing the landscape and its features (Machar, 2012b). Their availability, up-to-datedness and a highly diverse structure (with respect to both content and format), however, pose some problems. The accuracy and detail of input data influence the quality of consequent analyses and outputs (Hlásny, 2007). Overviews of individual datasets available in the $\mathrm{CR}$ and suitable for landscape analyses are presented by Pauknerová and Kučera (1997) and Pechanec (2012).

Digital landscape maps play a key role in GIS, as their primary focus is the integration of several environmental phenomena and their temporal and spatial modelling (Tomlinson, 2003; Pechanec et al., 2011a). With respect to implementation, such GIS must be equipped with a relevant (expert) database. Landscape maps are cartographic models of spatial differentiation and integration at the landscape level of the Earth, changes in its structure from place to place and dynamic trends. They should include cartographical principles (Brus et al., 2010). In addition, maps of contemporary (current) landscape also provide information on land use and they are an essential source of much information for any landscape study (Hrnčiarová, 2001; Kolejka, 1987; Pechanec et al., 2011b).

The process of landscape analysis evaluates its structure, function and dynamics. Particularly in the case of development studies and actual landscaping projects, the interest areas must be evaluated not only with respect to the proportional representation of individual forms of land use, but also with respect to the spatial distribution of individual forms of land use, as well as the number, shape and orientation of partial landscape segments (Hanna, 1999).
Substantiated structured landscaping measures may be proposed only on the basis of a detailed analysis of the current land use, with the physical geographic relations in the area taken into account (Brail and Klosterman, 2001). GIS offer a wide spectrum of spatial analyses and modelling, which find excellent application in landscape studies (Zhang et al., 2011), as well as in the analyses of habitats of individual plant and animal species and their mutual relations (Nelson and Boots, 2005; Liang et al., 2011). They allow researchers to conduct complex assessments of timechangeable characteristics (Antwi et al., 2008; Otýpková et al., 2011; Machar et al., 2014), assessments partly derived from the evaluators' subjective perceptions (aesthetic characteristics) or evaluations of groups of features, such as geosystem complexes which create conditions for preserving biodiversity (e.g. Carlson et al., 2004; Hamilton, 2005; Pechanec et al., 2014). Apart from the basic user interface, GIS allows the application of specialised modules and tools for landscape structure analyses.

The application of GIS in landscape management brings several benefits: both for confrontation and communication among specialists who used to take landscape-oriented decisions only within the narrow scope of their individual professions; they help visualise problems and hazards; and, these systems allow the simulation of effects that some phenomena might have and thus help minimise incorrect decisions.

With respect to the efficiency of using geoinformation technology in landscape management, the application of analytical tools is desirable thanks to the speed and exactness of processing they offer. The major strength of GIS is manifested particularly in the process of creating new information layers (maps) from data already obtained, with the possibility of alternative scenario modelling (Pechanec et al., 2011a; Zhang et al., 2011).

PMM has been applied as well at the national level in the Slovak Republic (Feranec and Nováček, 2009) and in the historical context of mountain Slovak landscapes (Hresko et al., 2015). In Central Europe, there are numerous regional and local studies which specify changes in landscape matrices: for example, in Austria by Krausmann et al. (2003); Kowalska (2012) in the middle Vistula River valley in Poland; Hohensinner et al. (2004) around the Danube River; and Deák (2007) who covers habitat changes and landscape use in the South-Tisza-valley, Hungary. Changes in post-war agricultural land use in the former East Germany in connection with the Elbe flood peaks are described by van der Ploeg and Schweigert (2001) and Feranec et al. (2010). The results show close relationships between changes in socio-economic metabolism and changes in land use and land cover.

In the Czech Republic, several authors have studied the temporal and spatial development of the landscape matrix at various scales, drawing on similar methods (Demek et al., 2008; Cebecauerová, 2007; Havlíček et al., 2012; Machar et al., 2009). Historical analyses conducted in various areas were based on the study of cartographic materials and other archive documents (e.g. Lacina et al., 2007 in Železna Ruda town and its surroundings; Skaloš et al., 2011 in the lowland area of Nové Dvory and Žehušice; Demek et al. 2012, in the south-eastern part of the CR). Skokanová et al. (2012) studied the development of land use and the main processes in the area around Zlín. Bičík et al. (2015) introduced an analysis of the socio-economics factors. There are many studies applying the PMM at the regional scale in 
specific areas, such as the catchment area (e.g. Kilianová et al., 2009, in the Trkmanka catchment). In addition, Machar (2013a) studied long-term changes in the landscape matrix in the Morava River floodplain under anthropogenic impact; Demek et al. (2008) evaluated landscape changes in the Dyjskosvratecky úval Graben and Dolnomoravský úval Graben; and Havlíček et al. (2009) demonstrated long-term changes in land use in the Litava River basin.

The principal aim of this article is to present the application of PMM to analyse changes in the alluvial landscape. It is particularly timely in the context of the increasing frequency of flood events in the alluvial plains of rivers of Central Europe. At present, the Morava River floodplain is an example of a cultural landscape in which most ecosystems are affected by the socio-economic activities of society.

\section{Materials and methods}

\subsection{Study area}

The study area represents the alluvial landscape of the Morava River in the Czech Republic. The Morava River floodplain has been defined based on geological maps at the scale of $1: 50,000$ for project No. 206/97/0162: "Recovery of ecological continuum of Morava River" (Štěrba, 1999). The Morava River is a left tributary of the Danube River. It is the main river of the eastern part of the Czech Republic Moravia, which derives its name from it. The river originates on the Kralický Sněžník Mts. in the north-eastern part of Pardubice Region, near the border between the Czech Republic and Poland, and has a vaguely southward trajectory. The lower part of the river's course forms the border between the Czech Republic and Slovakia, and then between Austria and Slovakia (see Fig. 1).

The length of the Morava River from its source to the confluence with the Dyje River at the border of the Repblic is about $270 \mathrm{~km}$. The Morava River feeds the Danube River with an average discharge rate of $120 \mathrm{~m}^{3} . \mathrm{s}^{-1}$ gathered from a drainage area of 26,658 square kilometres. The Morava River is unusual in that it is a European black water river. The river's longest tributary is Dyje River (Thaya River), flowing in at the tripoint of Austria, the Czech Republic and Slovakia. The biggest tributary from the left is Bečva River.

The Morava River floodplain is only a few metres wide in the upper reaches and widens gradually towards the south up a width of several kilometres. The boundary of the study area was formed by the boundary of the Quaternary fluvial sediments of the Morava River according to Šterrba et al. (1999). The surface area of the studied floodplain was 635.7 square kilometres, and the elevation ranged from $900 \mathrm{~m}$ a. s. 1. (narrow floodplain of the Morava in the Kralický Sněžník Mts.) to $151 \mathrm{~m}$ a. s. 1 . (confluence of the Morava and Dyje Rivers).

Adjustments to the river stream were carried out first on the middle part, in the first half of the nineteenth century, and the lower part was regulated at the end of the century. From 1969 to 1976 the Morava River was regulated between Hodonín town and Lanžhot village. In 1977, the last summer flood occurred. Changes at the Dyje and Morava Rivers confluence were finished in 1988, and the last meanders were cut. For two decades, regardless of climatic conditions, water levels inevitably dropped and ground water levels have decreased (Tab. 1). In the period under review, the Morava

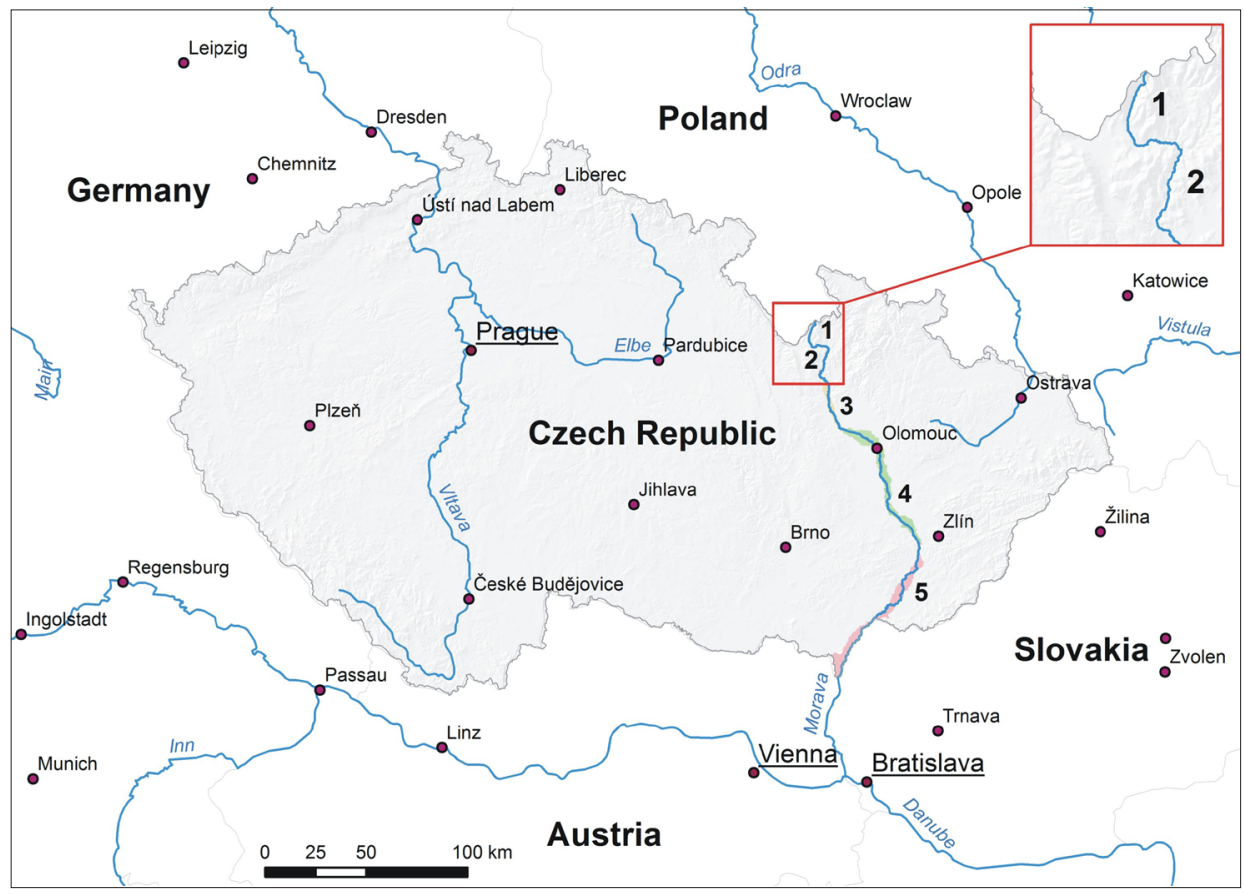

Fig. 1: Location of the Morava River and sectors of the Morava River floodplain (Sector 1 - Kralický Sněžník Mts.; Sector 2 -Branenská vrchovina Highland; Sector 3-Mohelnická brázda Furrow; Sector 4-Hornomoravský úval Graben; and Sector 5-Dolnomoravský úval Graben). Source: authors

\begin{tabular}{lccccr}
\hline & $\mathbf{1 8 3 6}$ & $\mathbf{1 8 7 7}$ & $\mathbf{1 9 5 3}$ & $\mathbf{1 9 9 9}$ & $\mathbf{2 0 1 0}$ \\
\hline Length of Morava River & 334.9 & 329.5 & 285.4 & 268.0 & 269.3 \\
Length change & & -5.3 & -44.2 & -17.3 & 1.3 \\
\hline
\end{tabular}

Tab. 1: Length of the Morava River (km). Source: authors' calculations 
River was reduced approximately by $67 \mathrm{~km}$. The largest interventions were conducted in the first half of the $20^{\text {th }}$ century on the middle and lower part of river. The most affected parts were Mohelnická brázda Furrow (Sector 3; about $6 \mathrm{~km}$ ), Hornomoravský úval Graben (Sector 4; $13 \mathrm{~km}$ ) and Dolnomoravský úval Graben (Sector 5; 48 km).

Regulated water beds with impermeable shores prevent replenishment of ground water by soaking. The level of ground water is the main determinant of the quality of the root systems of floodplain forest, mainly of oak and ash. The depth of the root systems of main bottomland woody plants of age 51-104 years does not reach over 2 m (Bagar and Klimánek, 1999), so when ground water level drops, the conditions of bottom land woody plants deteriorate. Research in this area has shown that some growth reactions of ash and oak are affected by the lowered level of ground water (Maděra and Úradníček, 2000).

In order to carry out further spatial analysis, the floodplain area was split/divided into five sectors named after geomorphological units (see Mackovčin et al., 2009), as follows: Kralický Sněžník Mts. (Sector 1) - northern, the highest part of the floodplain in the source area of the Morava River (a wide valley floor filled with river sediments); Branenská vrchovina Highland (Sector 2) and Mohelnická brázda Furrow (Sector 3), representing the upper parts of the middle course of Morava River; and Hornomoravský úval Graben (Sector 4) and Dolnomoravský úval Graben (Sector 5), wide floodplain of the lower course of the Morava River (Fig. 1).

\subsection{Data and methods}

Assessment of the temporal changes was carried out in the GIS environment at a uniform scale of $1: 25,000$. Map sheets of the $2^{\text {nd }}$ military mapping from 1836-1840, the $3^{\text {rd }}$ military mapping from $1876-1878$, and state maps at $1: 5,000$, derived from the period around 1953, were analysed. Further, field investigations from 1995-1997 (Štěrba et al., 1999), and the situation from 2010 were used. Cartographic materials used as a base layer for floodplain condition around 1836 were the sheets of the $2^{\text {nd }}$ military mapping. This Second military mapping, called Franz's, was carried out in Moravia in 1836-1840 (1842-1852 in Bohemia) using a fathom scale of 1:28,800. Its base layer is the stable land registry, founded by patent in 1817 . Numeric geodetic mapping in Moravia and Silesia was carried out by trigonometrical points of $1^{\text {st }}$ to $3^{\text {rd }}$ degree of St. Stephan's system (Císař et al., 1966). The pantographically-shrinked contents of the land registry map $(1: 2,880)$ were used as a graphical topographical base layer. From the military point of view, important topographical data (surfaces) were denoted using 11 colours and landscape configuration was shown using Lehmann hatching. Altitudes in Vienna fathoms were shown only for trigonometrical points (Boguszak and Šlitr, 1962).

Another base layer was comprised of maps from the $3^{\text {rd }}$ military mapping from 1876 to 1880 . This third military mapping was carried out in the entire Austria-Hungary Empire in the second half of the $19^{\text {th }}$ century (1867-1887) at the scale of $1: 25,000$ (Čapek et al., 1992). In the period 1876-1878, a topographical map of Moravia was created at the scale of $1: 25,000$, from which other maps were derived (special $1: 75,000$, general $1: 200,000$, and brief $1: 750,000$ ).

In 1946 the unified map works on "State map economic $1: 5,000$ " (SMH-5) were started. Topography is shown in this SMH-5 map, altimetry is expressed using spot heights, and contour lines are shown with base interval of $1 \mathrm{~m}$. Its prints have three colours: topography is grey, altimetry is brown, and description is in black. Because the map could not be created quickly, in 1950 the decision was made to create a temporary map work of the entire area of the state (except areas already shown in the economic map) called: "State map 1 :5,000-derived" (SMO-5) (http://geoportal.cuzk.cz/). For this map, the original print has two colours - contents in black and contours in brown (Boguszak and Císař, 1961). Topographical and topical contents of these maps at the scale of $1: 5,000$ were manually transferred into base maps of scale $1: 25,000$. The sheets position was derived from a planned (but according to a personal communication from R. Čapek, never published) map at $1: 50,000$, which was divided into 10 columns and 10 layers of map sheets at $1: 5,000$ (Hojovec et al., 1987). For the creation of the map of floodplain soils of the Morava River around 1953, 264 map sheets of State map 1 : 5,000-derived (SMO-5) were used.

The situation from 1999 was taken from national project No. 206/97/0162: "Recovery of ecological continuum of Morava River" (Štěrba et al., 1999). For this project, base layers were supplied by single municipalities, where the Morava River flows. The authors of the grant task had digital maps of soil utilisation and the river network at their disposal. Digitalisation of these maps was carried out from maps at the scale of $1: 25,000$, published around 1994. After improvements in accuracy and the addition of information gathered by field investigation, these maps were considered as representing conditions in 1999.

The current condition (2010) was created using a combination of digitalisation of aerial imagery, base map layers of the national portal CENIA, and field investigations. These methods were used for the creation of actual floodplain land use of the Morava River in 2010. The prevalent method was the interpretation of orthophotomaps. Field investigation was used mostly for obtaining additional information in areas hard to interpret and unclear areas. Areal imagery was taken by GEODIS BRNO, s. r. o. in the period 2008-2010, their transfer was carried out using a WMS web services via the national geoportal run by CENIA agency. WMS is a map service which enables views of map layers in intranet or Internet environments (Longley et al., 2010).

The categories used in forming the landscape matrix were identified based on an available visual key (Skaloš et al., 2011). Within the study area, the following categories were identified: Forests, Meadows, Pastures, Arable land, Gardens and Orchards, Urban areas, Water surface and Transport areas or others. The level of classification used here reflects the best possible level that can be identified on old maps (Mackovčin, 2009).

Forest areas were mapped without differentiation of coniferous and broad-leaved forests. Small forests and bosques were classified as forests if their size was at least 1.5 ha (linear dimension at least $0.5 \mathrm{~cm}$ ). Bushes and bushy formations were classified on one of the military maps, but were not used on maps from the 1950s; therefore, their areas were also included in the forest category. Boundaries of land utilisation are lines between adjacent areas, used for different purposes, which do not comprise another line element. Meadows and pastures were identified based on their symbology in maps.

The cartographic contents of the digital historical maps were compared with a digital map of the current land use of the Morava River floodplain, and thus the information on the representation of all mapped land use categories in 
different time periods was obtained. This information was organised into a data system that allows analysis of changes in the evolution of the landscape and individual landscape elements, in the studied time period.

The digitisation was followed by the processing of a detailed network of digitised lines. Each point was assigned by coordinates and an unique identifier to which additional descriptive information was linked. Each point was then assigned information from the table of codes expressing the use of the area. Finally, the names of towns, forest units and water courses were created in the ArcGIS attribute table. After further necessary topological adjustments, a digital map was created which could be then statistically analysed using traditional GIS tools. The resulting statistical data (number of individual spots, their size, sum, length of water courses, etc.) were processed into tables and graphs that allowed interpretation of results.

\section{Results}

\subsection{Development of land use in the entire floodplain area of the Morava River}

From 1836 to 2010 the entire floodplain of the Morava River has witnessed evolutionary periods from the land use point of view (Tab. 2). The most significant trend is the growth of areas of arable land during this period, reaching its peak at the end of $20^{\text {th }}$ century, with a slight subsequent decrease. The dynamics of the growth of arable land has its effect also in the spatial structure of the land. At the beginning of the period, the matrix of land is formed by meadows and pastures (47.54\%), forests $(27.89 \%)$ and arable land (21.5\%). Towards the end of $19^{\text {th }}$ century (1877), meadows and pastures still cover the majority of the land (38.72\%), but the area of arable lands (189.45 square kilometres, i.e. $29.8 \%$ of the floodplain area) is already higher than the area of forests (158.2 square kilometres, i.e. $24.89 \%$ ). In the $1950 \mathrm{~s}$, arable land already covered the majority of the area (37.77\%), with meadows and pastures (26.81\%), the area of which had surpassed the forest areas (23.89\%). Arable lands (51.87\% of the Morava River floodplain in 1999) are dominant at the end of $20^{\text {th }}$ century. Forest areas are the second highest percentage $(25.53 \%)$, while meadows and pastures cover only $8.48 \%$ of the area. At present (2010), the lands of the Morava River floodplain are covered by arable land at $47.14 \%$ and forests at $27.81 \%$, while meadows and pastures cover only $7.94 \%$ of the area.
Changes in land use also affect changes in the appearance and character of the land, land structure and biodiversity, in each part of the floodplain. The floodplain character, descending and widening along the water stream, is changing along with changing physical geographical conditions and its use. Therefore, one can find quantitative differences in particular parts of the floodplain of the Morava River.

In this floodplain, the surface is constituted mostly from stable ecosystems - meadows, pastures and forest ecosystems. From the species point of view, completely changed agroecosystems, i.e. fields, have dominated the area since second half of the $20^{\text {th }}$ century.

In 1836, the Morava River floodplain was relatively well preserved from the ecological point of view. Most of the surface area was composed of meadows, pastures and forests. Arable land prevailed in the Morava River floodplain in the second half of the $20^{\text {th }}$ century. The trend of a growing area of human settlements within the floodplain is discernible over the whole time period.

Changes of land use in the Morava River floodplain from 1836 to the present are shown in Table 2. The table shows that spatial changes of different land use categories in the Morava River floodplain in different time periods are visible. Forests represent the most stable areas. The maximum decrease of their surface area by 25.43 square kilometres (i.e. 4.00\%) was recorded in 1953 as compared to the situation in 1836 . At the present, forests cover $27.81 \%$ of the Morava River floodplain. The area of forests decreased by about $0.08 \%$ between the time periods, however, the trend has reversed since 1953.

Meadows and pastures, which accounted for 302.22 square kilometres (i.e. 47.54\%) at the beginning of the studied period, almost disappeared from the alluvial landscape. Over time, their area has declined to only 53.94 square kilometres (i.e. 8.48\%). The loss of these important landscape elements in the Morava River floodplain was caused by their conversion to arable land. The area of arable land increased 2.5 times during the studied time period (from $21.5 \%$ to $51.87 \%$ ), which is a notable increase. Furthermore, a substantial portion of arable land has been added in the last decades compared to previous periods.

A very large increase in settlements was recorded. Their size increased from an original 16.3 square kilometres (i.e. $2.56 \%$ ) to 75.54 square kilometres (i.e. $11.88 \%$ ) in 2010. The size of urban areas within the floodplain has increased sharply since the turn of the $19^{\text {th }}$ and $20^{\text {th }}$ century and especially in the second half of the $20^{\text {th }}$ century. This

\begin{tabular}{lrrrrrrrrrrr}
\hline & \multicolumn{2}{c}{$\mathbf{1 8 3 6}$} & \multicolumn{2}{c}{$\mathbf{1 8 7 7}$} & \multicolumn{2}{c}{$\mathbf{1 9 5 3}$} & \multicolumn{2}{c}{$\mathbf{1 9 9 9}$} & \multicolumn{2}{c}{$\mathbf{2 0 1 0}$} \\
\cline { 2 - 12 } & km sq. & $\%$ & km sq. & $\%$ & km sq. & $\%$ & km sq. & $\%$ & km sq. & $\%$ \\
\hline Forests & 177.27 & 27.89 & 158.20 & 24.89 & 151.84 & 23.89 & 162.30 & 25.53 & 176.79 & 27.81 \\
Meadows and Pastures & 302.22 & 47.54 & 246.13 & 38.72 & 170.45 & 26.81 & 53.94 & 8.48 & 50.47 & 7.94 \\
Arable land & 136.65 & 21.50 & 189.45 & 29.80 & 240.08 & 37.77 & 329.72 & 51.87 & 299.68 & 47.14 \\
Gardens and orchards & 0.85 & 0.13 & 7.03 & 1.11 & 14.18 & 2.23 & 0.47 & 0.07 & 3.46 & 0.54 \\
Settlements & 16.30 & 2.56 & 23.41 & 3.68 & 38.22 & 6.01 & 66.23 & 10.42 & 75.54 & 11.88 \\
Water surfaces & 2.02 & 0.32 & 10.85 & 1.71 & 18.78 & 2.95 & 22.65 & 3.56 & 28.49 & 4.48 \\
Transport areas & 0.39 & 0.06 & 0.63 & 0.10 & 2.15 & 0.34 & 0.39 & 0.06 & 1.27 & 0.21 \\
Total & $\mathbf{6 3 , 5 7 0}$ & $\mathbf{1 0 0}$ & $\mathbf{6 3 , 5 7 0}$ & $\mathbf{1 0 0}$ & $\mathbf{6 3 , 5 7 0}$ & $\mathbf{1 0 0}$ & $\mathbf{6 3 , 5 7 0}$ & $\mathbf{1 0 0}$ & $\mathbf{6 3 , 5 7 0}$ & $\mathbf{1 0 0}$ \\
\hline
\end{tabular}

Tab. 2: Development of land use in the Morava River floodplain

Source: authors' calculations 
change can be explained by the development of industry, whose production facilities were located in the floodplain. Since the $1950 \mathrm{~s}$, when large-scale agriculture originated and agricultural cooperatives were established, the area of settlements has been enlarged by these economically and agriculturally used areas. Residential areas of towns and cities have expanded too, which is related to population growth and migration into them.

Transport areas (railway stations and their adjacent transshipment and manipulation areas) were mapped within the built-up areas. Some railway stations, which were located outside of town in the $19^{\text {th }}$ century, are now part of the urban area. New rail lines have been built over time. The surface area of transport infrastructure has therefore increased from an original $0.06 \%$ (in 1836) to the current $0.21 \%$ of the floodplain area.

The extent of floodplain forests is rather stable in the area of interest. Despite that, the extent of floodplain forests decreased (1836-1953) but then increased to their original extent. Generally, changes in forest areas happened within single parts of the forest. Only in one case was there a complete clearance of an isolated complex of floodplain forest. On the other hand, it happened only in a few cases that the current extent of single sections of forest is the largest in the period under consideration; 124.7 square kilometres of forest areas (i.e. $19.6 \%$ of the territory in the period of 1836-1953) and 115.9 square kilometres of forest areas (i.e. $18.2 \%$ of the territory in the period 1936-1999) were stable areas, i.e. they remained forest areas in the period. When expressing the persistence (the proportionate representation of stable areas relative to the areas at the starting point), the persistence of forest areas is 70.3 (18361953) and 60.4 (1936-1999) which can be rated as high stability. Settlements can be rated similarly. Water surfaces and meadows and pastures, on the other hand, have a very low persistence.

\subsection{Land use changes in the five sectors of the Morava River floodplain, 1836-1999}

When changes are observed in the defined sectors of the Morava River floodplain, they are very different. In areas which were mostly covered by arable land at the beginning of the period, changes are minor. Conversely, areas with a high percentage of grassy areas have undergone major changes.

Meadow and pastures formed $47.54 \%$ of entire area in the period 1836-1840 (Fig. 2), and almost $28 \%$ of the surface was forested. In contrast with ancient forestation, the actual forest area is not large but in this period it is the largest observed. The spatial pattern is not uniform - the most forested area is in the south - Dolnomoravský úval Graben (Sector 5).

The northern part of the Morava River floodplain on the slopes of Kralický Sněžník Mts. (Sector 1) is covered by forests, and in open valleys we can find meadows. In areas where the floodplain widens, near Červený Potok village, we can see fields as well. Forest areas in this area are located only at the edges of the floodplain, where they descend from valley slopes. In comparison, the floodplain in Branenská vrchovina Highland (Sector 2) has a very small percentage of forests (1.9\%). The major vegetation components in this part of the floodplain are meadows and pastures (46.7\%). Very little forest and bosques can be found in Sector 3, Mohelnická brázda Furrow, only 0.6\%. From Stavěšice village southwards there are meadows, which are then connected to the forest areas of the Litovelské Pomoraví Protected Landscape Area (PLA).
In Hornomoravský úval Graben (Sector 4) forests form $25.9 \%$ of the area, but their distribution is uneven. In the northern part of this sector, mostly forests of the Litovelské Pomoraví PLA are located, but in the floodplain segment between Olomouc city and Tovačov town there are no forests except for the pheasantry Království. In contrast, larger forest areas are located in the southern part of Hornomoravský úval Graben (Sector 4). In this sub-area, an almost continuous forest area is located on the left bank of the Morava River. There is an important complex of continuous forests between the Morava and Malá Bečva Rivers. Meadows and pastures, the prevailing vegetation component (41.8\%), are located unevenly. In most cases they follow the forests of water streams. Dolnomoravský úval Graben (Sector 5), has a high percentage (38.5\%) of forests, most of them located in the area of the confluence of the Morava and Dyje Rivers, much of it a quite preserved complex.

In the period of the $3^{\text {rd }}$ military mapping (Fig. 3), meadows and pastures still cover the major part of the Morava River floodplain area, $38.7 \%$ of the total area. Arable land covers almost one third of the floodplain and $24.9 \%$ are forest areas. Settlements are located mostly on the outskirts of the floodplain, covering only the edge or a small part of it, although some settlements are exceptions, e.g. Olomouc city, Uherské Hradiště city, etc. Water surfaces cover only $1.7 \%$ of the floodplain.

The highest altitudes in the floodplain areas of the Kralický Sněžník Mts. (Sector 1) are covered by forests, followed by meadows at $68 \%$. The floodplain land use is significantly changing, with arable land forming a majority. Forest areas in Sector 2 (Branenská vrchovina Highland) in the floodplain are located only marginally $(0.16 \%)$, only as line of riparian woods following river beds, and in the Mohelnická brázda Furrow (Sector 3) forests are also rare $(1.5 \%)$

When the Morava River enters Hornomoravský úval Graben (Sector 4), the floodplain widens and the river bifurcates into arms that flow from north-west to southeast through the forests and meadows of the Litovelské Pomoraví PLA. Forests and meadows cover $50 \%$ of the area of this local floodplain. The floodplain segment south of Olomouc is the most cultivated part, as arable land forms $60 \%$ of the area. Forest areas cover only $2 \%$ of this section. The southern part of the Hornomoravský úval Graben (Sector 4) is covered by forests at about $27 \%$, and the forests are surrounded by meadows and pastures, which form $45 \%$ of the area of this floodplain segment.

In the northern part of Dolnomoravský úval Graben (Sector 5) a very colourful mosaic of various uses is found. In the vicinity of the Morava River bed, one finds meadows (53\%) and forests $(21 \%)$. Arable land, which forms around one third of the area, is located often at the edge of the floodplain, only rarely near the water stream and mostly near settlements. In the southern part, the land appearance changes dramatically from a heterogeneous mosaic to large continuous units. Forests form 50\% of the area, $43.9 \%$ consists of meadows, following the forests from the western side.

In the period of mid- $20^{\text {th }}$ century (Fig. 4) arable land forms the majority use of the floodplain of the Morava River, taking up to $37 \%$. Forest areas are recorded at their smallest extent in this period, having dropped to 23.89\%. Meadows and pastures take up an area of 170.45 square kilometres, i.e. $26.81 \%$. Sources of spatial information are scarce in showing vegetation as neither coastal forests nor as dispersed 
vegetation is recorded. Forest areas are drawn in a detailed way within the larger scale, but with no information about the type (coniferous - broad-leaved)

The northern part of the study area at the slopes of Kralický Sněžník Mts. (Sector 1) is characterised by forests, which together with small forests and bosques in the valley floodplain up to Hanušovice town, form $23.5 \%$ of the area. They are located near the water stream, or descend from valley slopes down to the floodplain borders. In comparison, Branenská vrchovina Highland (Sector 2) is highly arable: arable land forms $33.6 \%$ of the area, while forest areas comprise only $2.4 \%$.

The Morava River floodplain in Mohelnická brázda Furrow (Sector 3) is highly arable - arable land forms over $52 \%$.
More grassland is located to the south, where meadows are followed by the forests of the Litovelské Pomoraví PLA, but overall there is only a small percentage of forests $(3.15 \%)$.

In some areas of (Hornomoravský úval Graben) (Sector 4) meadows are almost absent. Forests are condensed into larger bodies (Litovelské Pomoraví PLA, Království, Tovačovský Forest), comprising up to $21 \%$ of the area. The northern part of Dolnomoravský úval Graben (Sector 5) is mostly arable around the settlements, but the southern forests and meadows form a majority, covering together more than $75 \%$ of the floodplain area.

Some elements are missing in the base layers for land use from 1999 (Fig. 5). Pastures were excluded from grasslands and the category of gardens and orchards is included as a

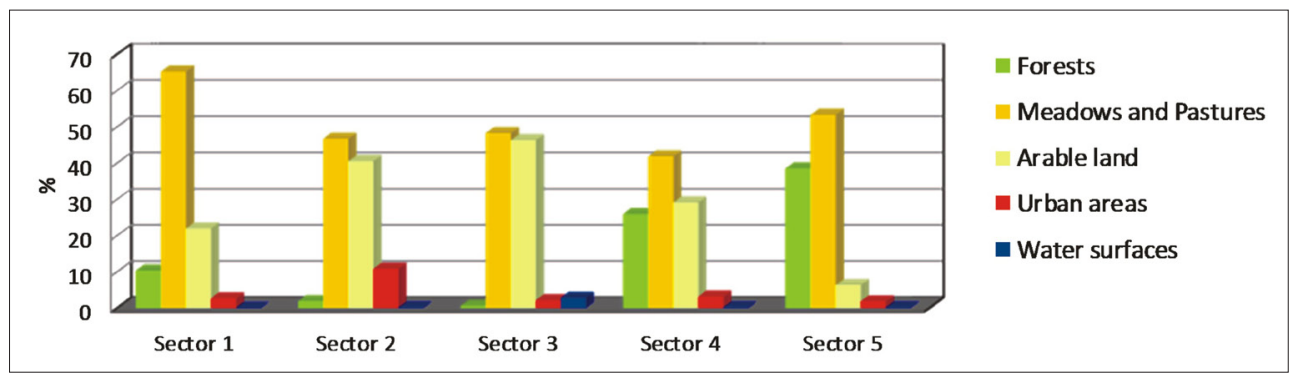

Fig. 2: Land use in floodplain sectors of the Morava River in 1836-1840 (in \%)

Source: authors' calculations

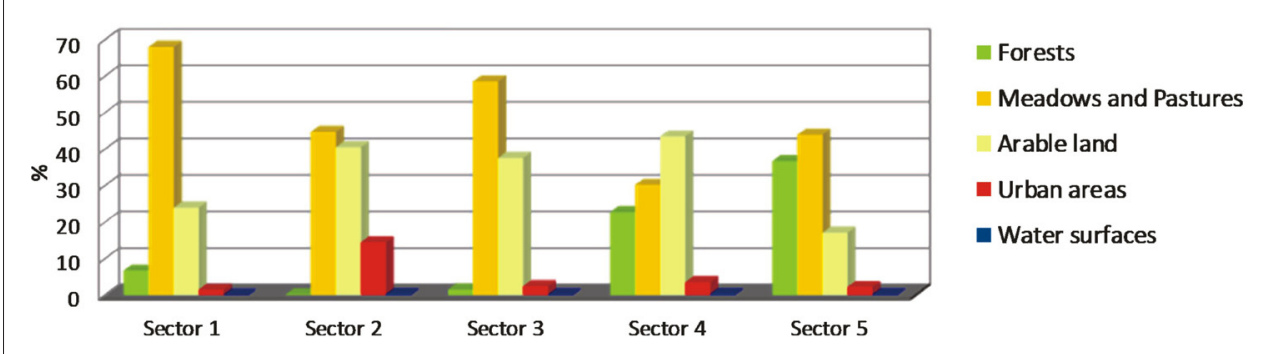

Fig. 3: Land use in floodplain sectors of the Morava River in 1876-1880 (in \%) Source: authors' calculations

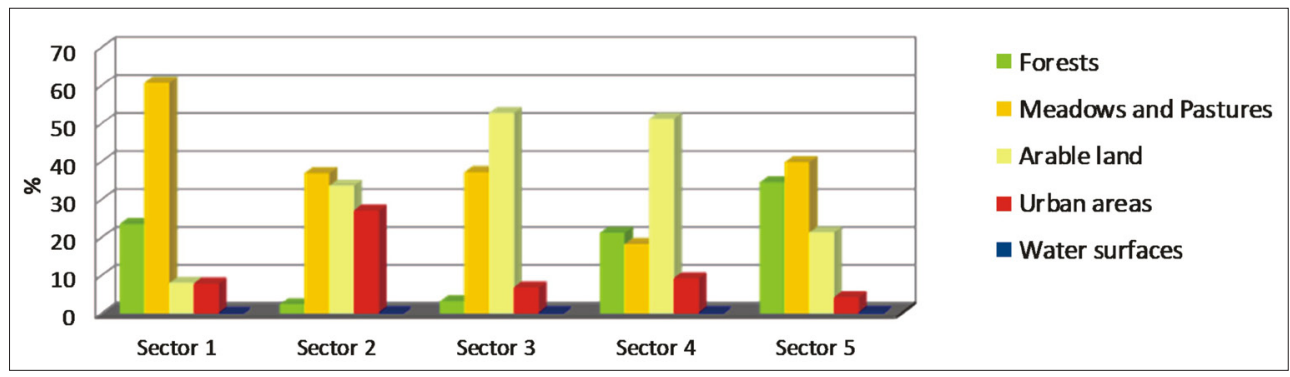

Fig. 4: Land use in floodplain sectors of the Morava River in 1953 (in \%)

Source: authors' calculations

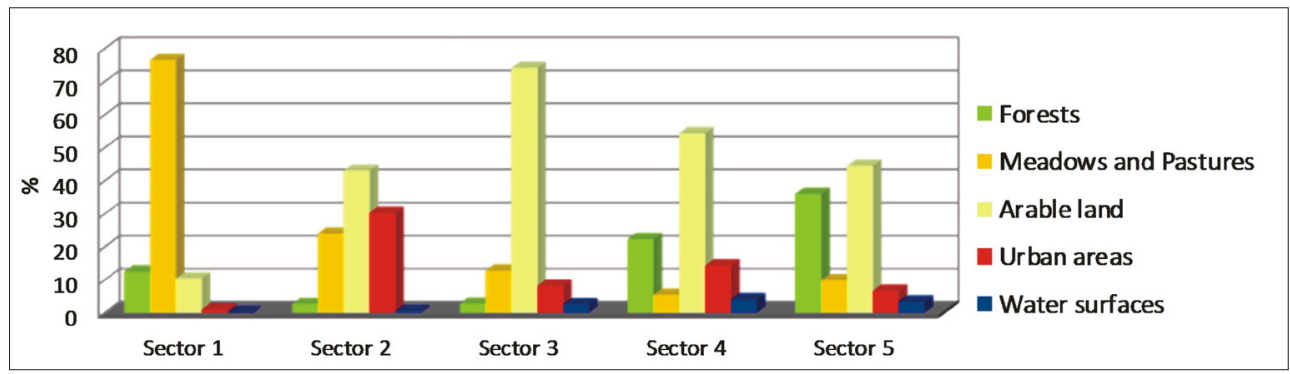

Fig. 5: Land use in floodplain sectors of the Morava River in 1999 (in \%)

Source: authors' calculations 
part of settlements. The dominant type of land use within the Morava River floodplain at the end of $2^{\text {nd }}$ millennium is arable land, comprising almost $52 \%$ of the area, with the second highest category as forests with $25.5 \%$ of area. Meadows form $8.5 \%$ and settlements around $10.4 \%$ of the area. Water surfaces are an eminent land element, covering 3.6\% of Morava River floodplain.

In Kralický Sněžník Mts. (Sector 1), forests are located in the lower floodplains at lower altitudes as the forests descend to the edges of the floodplains from surrounding slopes (Fig. 5). In this sector $12.4 \%$ of the area in total is forested. The floodplains in Branenská vrchovina Highland (Sector 2) have an area with very low percentage of forests (2.6\%), a small percentage of meadows (24\%), but high percentage of arable land (43\%). In Mohelnická brázda Furrow (Sector 3) arable land covers $74 \%$ of the area, and along water streams meadows are located, covering more than $12.7 \%$ of this segment. Forests are also located around streams as a part of coastal vegetation, on old, overgrowing dead arms. Apart from areas along water streams, they are located only around Bohuslavice village. The cover is $2.5 \%$ in total.

Hornomoravský úval Graben (Sector 4) at this time is covered by arable land to $54.2 \%$. Forests are located in complexes such as the Litovelské Pomoraví PLA, Království, Cítovský or Bítovský Forest - 22\% in total, while the middle part of this sector - from Olomouc city to Tovačov town - has only $11 \%$ forests.

Arable lands (44.9\%) dominate in Dolnomoravský úval Graben (Sector 5), in its northern part in particular, and forests are distributed evenly. In the northern part of the sector around $22 \%$ of the area is comprised of several forest complexes; in the southern part they form a compact body with an area of 68 square kilometres, i.e. $49 \%$ of this segment.

\subsection{Present land use situation}

The dominant type of land use in the Morava River floodplains was arable land in 2010, forming more than $47 \%$ of the area (Fig. 6). Forest areas comprise $27.8 \%$ of the area, which is close to forest conditions at the beginning of $19^{\text {th }}$ century. Meadows and pastures cover almost $8 \%$ and settlements cover $11.88 \%$ of the area, which confirms the rising trend of built-up areas in the floodplains. Water surfaces cover $4.5 \%$ of the Morava River floodplains.

In the Kralický Sněžník Mts. (Sector 1), the Morava River floodplains traverse forests, and at lower altitudes in the valley floodplains forests descend to their boundaries from valley slopes and cover $12.8 \%$ of the area. The floodplains in Branenská vrchovina Highland (Sector 2) have a very low percentage of forests (3\%), as forests are located around water streams as part of coastal vegetation, and in the vicinity of old, overgrowing dead arms. Apart from areas along water streams, they are located only around Bohuslavice village. Forest areas in Sector 3 (Mohelnická brázda Furrow) comprise more than $3 \%$ of the floodplain area.

Arable lands cover the majority (almost 54\%) of the Hornomoravský úval Graben (Sector 4), but forests form almost $23 \%$ of the floodplain area, in complexes such as Litovelské Pomoraví PLA, Království, Cítovský or Bítovský Forest. Dolnomoravský úval Graben (Sector 5) is currently covered by arable land at about $44 \%$, mostly in its northern part. Forests are distributed evenly: in the northern part of this sector about $22 \%$ of the area is forested in several complexes; in the southern part, they form a compact body with an area of 68 square kilometres, i.e. $40 \%$ of this segment. In sector 5, Dolnomoravský úval Graben forest areas cover $36.8 \%$ of the floodplains areas in total.

\section{Discussion}

The patch matrix model (PMM) provides a key to understanding land use systems and changes by interpreting quantitative landscape indicators (Hoechstetter et al. 2008). The PMM approach is limited to a two-dimensional representation of landscape structures, although efforts have been made to incorporate higher dimensions into its landscape representation (Stupariu et al., 2010). In the frame of analysis of historic landscape patterns, the PMM is reduced to available or interpretable data of land use classes (Kienast, 1993), such as shown in the Morava River floodplain Machar (2013b). But this disadvantage cannot be a handicap if our emphasis is on the evaluation of the human view of landscape, as in this article.

The lack of general relations between landscape structure and ecological processes can be overcome using the gradient model (GM), which represents landscape structure on the basis of continuous data, where the only discrete unit is a pixel or grid cell in a raster-based data model (McGarigal and Cushman, 2005). The GM represents landscape structure as continuous data, which usually originated from remote sensing, and using GM landscape models should help to improve our understanding of specieslandscape interactions (Cushman et al., 2010). GM-based models, however, usually evaluate only one variable of interest in the landscape - such as elevation or habitat quality for single species or green vegetation density - but this corresponds only to one land-cover type or category in the PMM (Lausch et al., 2015).

In European floodplains, the history of human press on the landscape plays a major role in shaping landscape structure (Trémolieres and Schnitzler, 2007). High land-use intensity in floodplain areas tends to control or fix vegetation patterns and landscape structure both in space and time. Such anthropogenic-dominated landscapes are primarily composed of homogenous areas with distinct boundaries

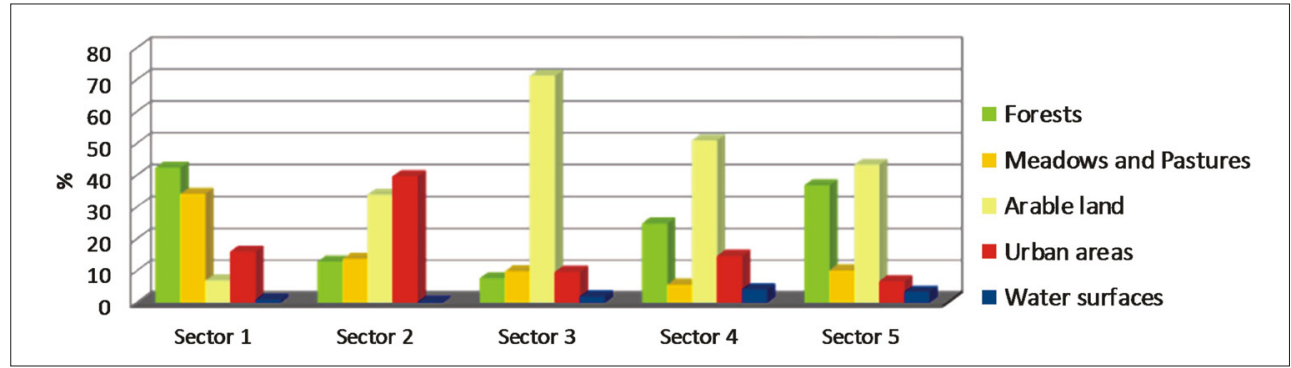

Fig. 6: Land use in floodplain sectors of the Morava River in 2010 (in \%)

Source: authors' calculations 
in a specific matrix. The resulting landscape structure in this landscape is therefore best represented with the PMM approach, distinguishing patches of uniform land-cover delineated by sharp boundaries (McGarigal et al., 2009). This is the main reason why we used the PMM in order to assess historical changes in landscape structure in the Morava River floodplain.

Potential perspectives for applications of the PMM currently suggest studies based on the joining of historical land structure changes with mathematical models for prediction of the future development of floodplain ecosystems (Simon et al., 2014), which can be implemented by landscape conservation management of the floodplain (Machar, 2010). The future predicted changes in floodplain landscape under climate change (Tockner and Stanford, 2002) enable researchers to consider the PPM based on GIS as a support decision tool for landscape management, as demonstrated in a case study from the Morava River floodplain by Kopecká et al. (2013).

The historical development of land use in the study area of the Morava River floodplain has been strongly influenced by social and economic conditions. These factors represent a possible influence on differences in the development of land use in the Czech Republic (CR) and in the study area. The first difference in the land use structure (Tab. 3) is the very high percentage of meadows in the Morava River floodplain, which already in 1836/1845 exceeded the Czech average by $33.73 \%$. It can be explained by natural conditions - the floodplain with its high ground water level and frequent floods did not allow other uses. Waterlogged meadows provided fodder but it was not necessary, and probably not even technically possible, to cultivate them. This also explains the low representation of arable land (compared to the country as a whole) and its location in acceptable parts of the floodplain. The initial low share of forests in the floodplain is surprising, as well as the following development tendency (relatively stable) compared to the CR. In the studied time period, the share of forests increased by $4.9 \%$ in the CR but decreased by $4 \%$ in the Morava River floodplain (status as of 1953).

It is worth noting that the share of built-up areas in the floodplain greatly exceeds their average share in the CR. It is five times higher even though some settlements are only partly situated within the floodplain. This situation can be explained by the location of ancient human dwellings and settlements in the proximity of rivers that were providing water and livelihood (Rulf, 1994). The settlement structure is therefore denser in the floodplain and its neighbourhood.

There are several different trends in the development of individual forms of land use in the $\mathrm{CR}$ and the floodplain in the studied period. Example of changes are visible on Figure 7 in Sector 4, Hornomoravský úval Graben, where the number of changes were calculated between 1877, 1953, 1999 and 2010. The momentuos loss of meadows and pastures in the Morava River floodplain and the dramatic increase in the area of arable land, which currently exceeds the average share in the CR by $9 \%$ indicate strong pressure on highly productive land in recent decades. The area of arable land in the floodplain increased by $219.3 \%$ of the original area (status in 1836). In contrast, in the CR it decreased to $79 \%$ of the original area (status in 1845). Meadows and pastures represent very dynamic land use categories in the Morava River floodplain. Their area decreased to $16.7 \%$ of the original size, while the biggest decrease was recorded in the second half of the $20^{\text {th }}$ century. The reduction of the area of forests, which were also transformed to arable land, has increased the difference in the share of forests in the floodplain and the CR. The trend of decreasing area of forests was reversed in the mid- $19^{\text {th }}$ century in the CR, but the same cannot be said for the Morava River floodplain, where this trend had not reversed before 1953.

There is a gradual upward trend in the size of built-up areas in the CR, as the size of built-up areas has increased by $278.3 \%$. In the floodplain it has increased by $464 \%$, while up to 1953 the area increased only by $234.5 \%$. The increase in the area of settlements in the floodplain is relatively recent, when there was a development of industry, largescale agriculture and housing construction. Flood risk was underestimated, probably due to drier climatic conditions in the $20^{\text {th }}$ century and awareness of the water management paradigm. Even so, floods are a natural factor in the development of floodplains and their vegetation cover.

It is interesting to monitor the development of water bodies. In the CR, the area of lakes, reservoirs and ponds has increased by $230 \%$, whereas in the Morava R. floodplain they represent the most dynamic land use category. Their size has increased by $1,400 \%$. This huge increase is linked to the formation of water reservoirs in the areas of extracted fluvial sand and gravel, which were established in the floodplain in relation to the development of the construction industry in recent decades.

\begin{tabular}{|c|c|c|c|c|c|c|c|c|c|c|}
\hline & MRF & CR & MRF & CR & MRF & CR & MRF & CR & MRF & CR \\
\hline & 1836 & 1845 & 1877 & 1897 & 1953 & 1948 & \multicolumn{2}{|c|}{1999} & \multicolumn{2}{|c|}{2010} \\
\hline Forests & 27.89 & 28.80 & 24.89 & 28.90 & 23.89 & 30.20 & 25.53 & 33.40 & 27.81 & 33.70 \\
\hline Meadows and Pastures & 47.54 & 17.60 & 38.72 & 14.20 & 26.81 & 12.90 & 8.48 & 11.30 & 7.94 & $12.5^{*}$ \\
\hline Arable land & 21.50 & 48.20 & 29.80 & 51.60 & 37.77 & 49.90 & 51.87 & 39.30 & 47.14 & 38.14 \\
\hline Gardens and orchards & 0.13 & 1.10 & 1.11 & 1.50 & 2.23 & 1.90 & 0.07 & 3.00 & 0.54 & 3.04 \\
\hline Urban areas & 2.56 & 0.60 & 3.68 & 0.70 & 6.01 & 1.10 & 10.42 & 1.96 & 11.88 & 1.67 \\
\hline Water surfaces & 0.32 & 0.90 & 1.71 & 0.50 & 2.95 & 0.60 & 3.56 & 1.99 & 4.48 & 2.07 \\
\hline Other & 0.06 & 2.80 & 0.10 & 3.00 & 0.34 & 3.40 & 0.06 & 9.05 & 0.21 & 8.89 \\
\hline Total & 100.0 & 100.0 & 100.0 & 100.0 & 100.0 & 100.0 & 100.0 & 100.0 & 100.0 & 100.0 \\
\hline
\end{tabular}

Tab. 3: Comparison (in \%) of the development of land use in the Morava River floodplain (MRF) and the Czech Republic (CR) over time. Sources: authors' calculations and Czech Statistical Office

Note: 'Since 2000 Czech Statistical Office does not record areas of 'Meadows and Pastures', but mark them in summary as 'Grasslands' 


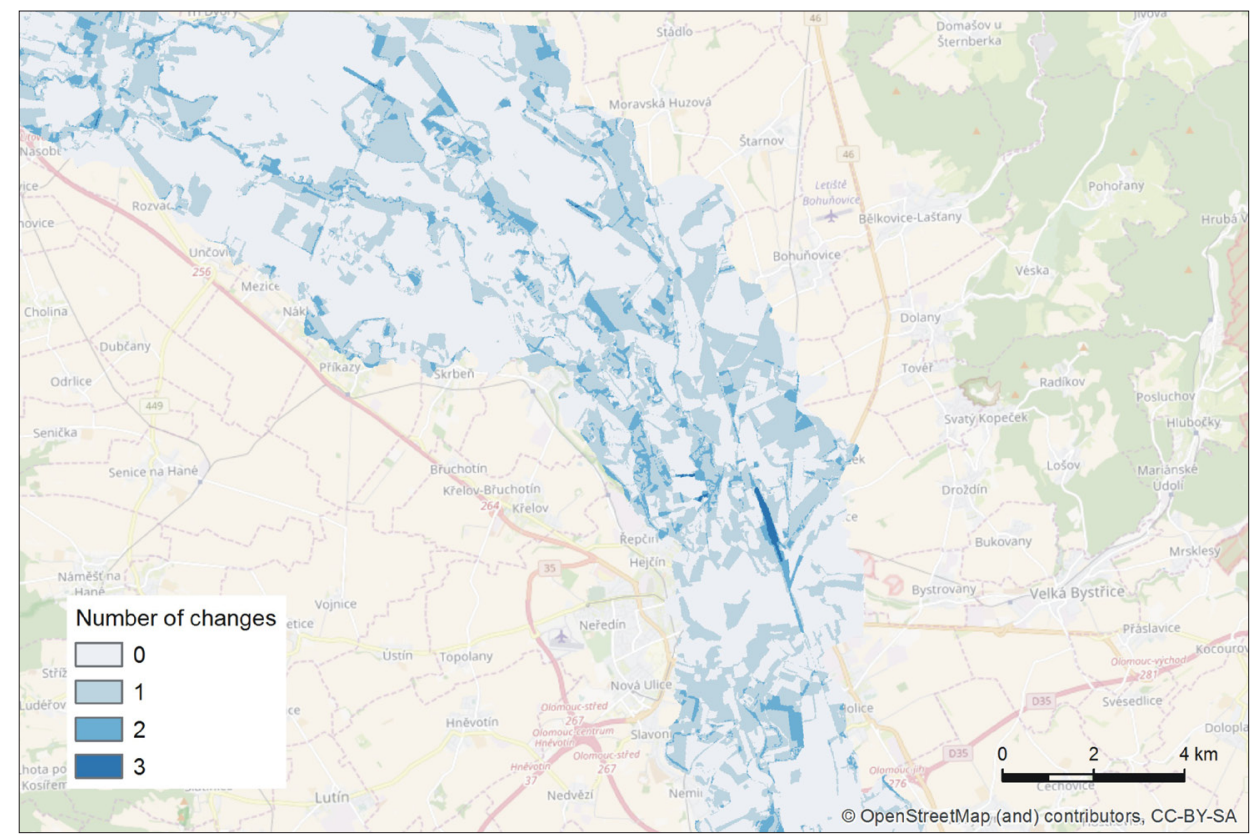

Fig. 7: Number of changes in the Hornomoravský úval Graben (Sector 4) between 1877, 1953, 1999 and 2010 Source: authors' calculations

When we compare the results of this study to the general development trends of the cultivated rural landscape in the CR, we can see that overall landscape heterogeneity and ecological stability increased during the $20^{\text {th }}$ century (Lipský, 1995). The change in the observed landscape attributes in the study area in the first half of the $20^{\text {th }}$ century was triggered by the transition from the 'coppice with standards' forest type to that of a high production forest (Machar, 2009). The intensive and centuries-old forest management processes in the floodplain forests of the Morava River is a conditionally natural state of the floodplain forest geobiocenoses, with unusually high biodiversity (Maděra et al., 2013).

The development dynamics of Central European floodplains is very rapid (Máčka, 2009; Salvati and Tombolini, 2013), from which follows a very dynamic ecological stability in the floodplains themselves. This was described by Buček and Lacina (1994, pp. 28-50) as the "fluvial dynamic series of successional floodplain biotopes". Research on the development of land use in the floodplains of European rivers provides similar results, despite the diversity of investigated areas, their size, scale, time periods and processing methods. Although such research projects may differ in their objectives and their methods, the results show similar trends in development.

In the last ten years there have been changes in the basin that are minor. One identifiable trend is the slight increase in grassland in the form of dry polders, as reactions to the devastating floods in 1997 and 2001 (Brus et al., 2013).

The dynamics of the various categories indicating the development of land use is influenced by many natural and socio-economic factors. In South Moravia Skokanová et al. (2012), Demek et al. (2008) set the category vineyard and hop field, and recreational area category in the second half of the $20^{\text {th }}$ century. Lacina et al. (2007) used comparable categories distinguishing between built-up rural / urban built-up areas. The development trends of the forests, arable areas and grasslands are therefore comparable to many conducted studies in South Moravia. Moreover, legends are similar with the definition provided by Mackovčin (2009)

\section{Conclusions}

In the area of the Morava River floodplain in the period from 1836 to 1999 , some important changes in the areas of forms of land use and their spatial arrangement are observable. Meadows and pastures, which formed the major proportion $(47.54 \%)$ of the land at the beginning of the investigated period, currently comprise only one fifth of its original area (7.94\%). For forests, the area decreased by $4 \%$ at most by 1953 , and since then has increased to its current value of $27.81 \%$. Arable land is a very dynamic form of land use and its area has increased from an original $21.5 \%$ to $51.87 \%$ by 1999 and currently at $47.14 \%$. The built-up area has recorded a great increase, with a share that has changed from $2.56 \%$ in 1836 to $11.88 \%$ now. The most dynamic change is reported for water surfaces, because at the end of $19^{\text {th }}$ century old ponds had ceased to exist and in the second half of $20^{\text {th }}$ century new water surfaces were created as a result of submerged sandy gravel quarries. Regulation of the Morava river bed began before 1836 (straightening and barraging of the stream between Kroměříz city and Kvasice village) with shortening by $10 \mathrm{~km}$, and the largest technical alterations were observed around 1900, when the river was shortened by $60 \mathrm{~km}$ in total.

From the analysis of relations between river bed adjustments and land use changes we can observe certain links. Forest areas did not go through such extreme changes as was the case for meadows. We can assume, however, that in the composition of species or the condition of forest ecosystems, we can track responses to altered local conditions.

Urban areas have grown greatly: their total area in the floodplain has increased by $464 \%$, which, given current conditions, cannot be assessed as a satisfactory situation. From the analyses carried out and computed coefficients of ecological stability (Kilianová et al. 2012), it follows that the land of the Morava R. floodplain has low ecological stability.

Land use changes in the Morava River floodplain have affected the overall appearance of the landscape impressively. During the last 175 years, the Morava River floodplain has 
changed from an extensively used agricultural landscape with prevailing permanent grassland to an intensively used agricultural landscape dominated by arable land.

Changing the landscape structure affects the performance of the ecosystem services provided by the river landscape. Further research is required on the rate of decline in the performance retention and sedimentation function in biophysical and economic units.

\section{Acknowledgment}

This paper is supported by the project of the Technology Agency of the Czech Republic: No. TA04020888.

\section{References:}

AL-ADAMAT, R., DIABAT, A., SHATNAWI, G. (2010): Combining GIS with multicriteria decision making for siting water harvesting ponds in Northern Jordan. Journal of Arid Environments, 74(11): 1471-1477.

ANTWI, E. K., KRAWCZYMSKI, R., WIEGLEB, G. (2008): Detecting the effect of disturbance on habitat diversity and land cover change in a post-mining area using GIS. Landscape and Urban Planning, 87(1): 22-32.

BAGAR, R., KLIMÁNEK, M. (1999): Hlavní př́ičiny a důsledky změněných ekologických podmínek v lesních ekosystémech lužní oblasti jižní Moravy. Ochrana přírody, 54(6): 178-182.

BENJAMIN, K., DOMON, G., BOUCHARD, A. (2005): Vegetation composition and succession of abandoned farmland: effects of ecological, historical and spatial factors. Landscape Ecology, (2005) 20: 627-647.

BIČÍK, I., KUPKOVÁ, L., JELEČEK, L., KABRDA, J., ŠTYCH, P., JANOUŠEK, Z., WINKLEROVÁ, J. (2015): Land Use Changes in Czechia 1845-2010. SocioEconomic Driving Forces. Heildelberg, Springer.

BOGUSZAK, F., CÍSAŘ, J. (1961): Vývoj mapového zobrazení území ČSSR. III. Díl. Mapování a měření českých zemí od pol. 18. stol. do poč. 20. století. Praha, Kartografický a reprodukční ústav.

BOGUSZAK, F., ŠLITR, J. (1962): Topografie. Praha, Státní nakladatelství technické literatury.

BRAIL, R. K., KLOSTERMAN, R.E. (2001): Planning Support Systems. Integrating GIS, models and visualization tools. ESRI Press, Redlands, CA.

BRUS, J., PECHANEC, V., KILIANOVÁ, H., MACHAR, I. (2013): The evolution of the floodplain forests as indicators of landscape changes in the alluvium of the Morava River. $21^{\text {st }}$ International Conference on Geoinformatics 2013, June 20-22, Geoinformatics 2013. Kai Feng; China.

BRUS, J., DOBEŠOVÁ, Z., KAŇOK, J., PECHANEC, V. (2010). Design of Intelligent System in Cartography. $9^{\text {th }}$ Roedunet IEEE International Conference, Sibiu, Romania.

BUČEK, A., LACINA, J. (1994): Biogeografické poměry. In: Vybrané fyzickogeografické aspekty pro revitalizaci nivy Dyje v úseku VD Nové Mlýny - soutok s Moravou (pp. 3035). Brno, Ústav geoniky AV ČR a ÚLBDT MZLU.

CARLSON, B., WANG, D., CAPEN, D., THOMPSON, E. (2004): An evaluation of GIS-derived landscape diversity units to guide landscape-level mapping of natural communities. Journal for Nature Conservation, 12(1): 15-23.
CEBECAUEROVÁ, M. (2007): Analýza a hodnotenie zmien štruktúry krajiny (na príklade části Borskej nížiny a Malých Karpát). Geographica Slovaca, 24. Bratislava, Geografický ústav SAV.

CLARK, F. S., SLUSHER, R. B. (2000): Using spatial analysis to drive reserve design: A case study of a national wildlife refuge in Indiana and Illinois (USA). Landscape Ecology, 15: $75-84$

CUSHMAN, S.A., GUTZWEILER, K., EVANS, J. S., MCGARIGAL, K. (2010): The gradient paradigm: a conceptual and analytical framework for landscape ecology. In: Cushman, S. A., Huettmann, F. [eds.]: Spatial Complexity, Informatics and Wildlife Conservation (pp. 83-108). New York, Springer.

CSO (2015): CzechStatistical Office, PublicDatabase[online]. [cit. 10.04.2015].Availableat:https://vdb.czso.cz/vdbvo/tabparam. jsp?voa =tabulka\&cislotab=ZPR9010CU\&\&kapitola_id=10

CÍSAŘ, J., BOGUSZAK, F., JANEČEK, J. (1966): Mapování. Praha, SNTL.

ČAPEK, R., MIKŠOVSKÝ, M., MUCHA, L. (1992): Geografická kartografie. Praha, Státní pedagogické nakladatelství.

DAUBER, J., HIRSCH, M., SIMMERING, D., WALDHARDT, R., OTTE, A., WOLTERS, V. (2003): Landscape structure as an indicators of biodiversity: Matrix effects on species richness. Agriculture, Ecosystems and Environment, 98: 321-329.

DEÁK, A. J. (2007): 200 years of habitat changes and landscape use in the South-Tisza-valley, Hungary. In: Okruszko, T., Maltby, E., Sztyłowicz, J., Šwiątek, D., Kotowski, W. [eds.]: Wetlands: Monitoring, Modelling and Management (pp. 45-54). London, Taylor \& Francis Group.

DEMEK, J., HAVLÍČEK, M., CHRUDINA,Z., MACKOVČIN,P. (2008): Changes in land-use and the river network of the Graben Dyjsko-svratecký úval (Czech Republic) in the last 242 years. Journal of Landscape Ecology (Brno), 1(2): $22-51$.

DEMEK, J., MACKOVČIN, P., SLAVÍK, P. (2012): Spatial and temporal trends in land-use changes of Central European landscapes in the last 170 years: a case study from the south-eastern part of the Czech Republic. Moravian Geographical Reports, 20(3): 2-22.

DRUGA, M., FALŤAN, V. (2014): Influences of environmental drivers on land cover structure and its long-term changes: a case study of the villages of Malachov and Podkonice in Slovakia. Moravian Geographical Reports, 22(3): 29-41.

FARINA, A., BELGRANO, A. (2006): The Eco-field Hypothesis: Toward a Cognitive Landscape. Landscape Ecology, 21(1): 5-17.

FERANEC, J., NOVÁČEK, J. (2009): The CORINE land cover database of Slovakia and its changes in the period 2000-2006. Moravian Geographical Reports, 17(3): 2-9.

FERANEC, J., JAFFRAIN, G., SOUKUP, T., HAZEU, G. (2010): Determining changes and flow in European landscapes 1990-2000 using CORINE land cover data. Applied Geography, 30(1): 19-65.

FORMAN, R. T. T., GODRON, M. (1993): Krajinná ekologie. Praha, Academia. 
GEOPORTÁL ČÚZK (2017): State map at scale of 1:5,000. [online]. [cit. 24.02.2017]. Available at: http:// geoportal.cuzk.cz/(S(32p4uwzxwfstkdm5a1u0wlrt))/ Default. aspx $? \operatorname{lng}=\mathrm{EN} \&$ mode $=$ TextMeta\&text $=\mathrm{dsady}$ mapy $5 \&$ side $=$ mapy $5 \&$ menu $=2224 \&$ head_tab $=$ sekce-02-gp

GERGEL, S. E. (2004): Spatial and non-spatial factors: When do they impact landscape indicators of watershed loading? Landscape Ecology, 20: 177-189.

GUSTAVSSON,E.,LENNARTSSON,T., EMANUELSSON,M. (2007): Land use more than 200 years ago explains current grassland plant diversity in a Swedish agricultural landscape. Biological Conservation, 138: 47-59.

HAMILTON, A. J. (2005): Species diversity or biodiversity? Journal of Environmental Management, 75: 89-92.

HANNA, K. C. (1999): GIS for landscape architects. ESRI Press, Redlands, CA.

HAVLÍČEK, M., BOROVEC, R., SVOBODA, J. (2009): Longterm changes in land use in the Litava River basin. Acta Pruhoniciana, 91: 31-37.

HAVLÍČEK, M., KREJČÍKOVÁ, B., CHRUDINA, Z., SVOBODA, J. (2012): Long-term land use development and changes in streams of the Kyjovka, Svratka and Velička river basins (Czech Republic). Moravian Geographical Reports, 20(1): 28-42.

HAVLÍČEK, M., PAVELKOVÁ-CHMELOVÁ, R., FRAJER, J., SKOKANOVÁ, H. (2014): The long-term development of water bodies in the context of land use: The Case of the Kyjovka and Trkmanka river basins (Czech Republic). Moravian Geographical Reports, 22(4): 39-50.

HLÁSNY, T. (2007): Geografické informačné systémy priestorové analýzy. Zvolen, Národné lesnícke centrum ZEPHYROS.

HOECHSTETTER, S., WALZ, U., DANG, L. H., THINH, N. X. (2008): Effects of topography and surface roughness in analyses of landscape structure - a proposal to modify the existing set of landscape metrics. Landscape Online, 3: $1-14$.

HOHENSINNER, S., HABERSACK, H., JUNGWIRTH, M., ZAUNER, G. (2004): Reconstruction of the Characteristics of a Natural Alluvial River-floodplain System and Hydromorphological Changes following Human Modifications: the Danube River (1912-1991). Research and Applications, 20: 25-41.

HOJOVEC, V., DANIŠ, M., HÁJEK, M., VEVERKA, B. (1987): Kartografie. Praha, Geodetický a kartografický podnik.

HRESKO, J., PETROVIC, F., MISOVICOVA, R. (2015): Mountain landscape archetypes of the Western Carpathians (Slovakia). Biodiversity and Conservation, 24 (13): 3269-3283.

HRNČIAROVÁ, T. (2001): Ekologická optimalizácia pol’nohospodárskej krajiny. Modelové územie Dolná Malanta. Bratislava, Veda.

KIENAST, F. (1993): Analysis of historic landscape patterns with a geographical information system - a methodological outline. Landscape Ecology, 8: 103-118.

KILIANOVÁ, H., PECHANEC, V., LACINA, J., HALAS, P. (2009): Ekotony V současné krajině: Analýza a modelování ekotonů $\mathrm{v}$ povodi Trkmanky. Olomouc, Univerzita Palackého v Olomouci.
KILIANOVÁ, H., PECHANEC, V., SVOBODOVÁ, J., MACHAR, I. (2012): Analysis of the evolution of the floodplain in the alluvium of the Morava River. Conference Proceedings SGEM 2012, $12^{\text {th }}$ International Multidisciplinary Scientific GeoConference. STEF92 Technology Ltd., Sofia, Bulgaria, IV: 1-8.

KOLEJKA， J. (1987): Landscape-historical Synthesis. Materials, Methods and Results. Ekólogia (ČSFR), 6(1): 51-62.

KOPECKÁ, V., MACHAR, I., BUČEK, A., KOPECKÝ, A. (2013): The Impact of Climate Changes on Sugar Beet Growing Conditions in the Czech Republic. Listy cukrovarnicke a reparske, 129(11): 326-329.

KOWALSKA, A. (2012): Changes in the Area of Protected Plant Communities in the Middle Vistula River valley in the second half of the $20^{\text {th }}$ century. Polish Journal of Ecology, 60(1): 19-30.

KRAUSMANN, F., HABERL, H., SCHULTZ, N. B., ERB K. H., DARGE, E., GAUBE, V. (2003): Land-use change and socioeconomic metabolism in Austria, Part I: Driving forces of land-use change: 1950-1995. Land Use Policy, 20(1): $1-20$.

KUBÍČEK, P., MULÍČKOVÁ, E., KONEČNÝ, M., KUČEROVÁ, J. (2011): Flood Management and Geoinformation Support within the Emergency Cycle (EU Example) In: Environmental Software Systems. Frameworks of eEnvironment (pp. 77-86). Chennai, India: Springer Berlin Heidelberg.

LACINA, D., DEMEK, J., MACKOVČIN, P., HAVLÍČEK, M. (2007): Land use changes in the town of Železna Ruda and its surroundings (Czech Republic) based on the analysis of historical maps from the period 1843-2005. Silva Gabreta, 13(3): 269-284.

LAUSCH, A., BLASCHKE, T., HAASE, D., HERZOG, F., SYRBE, R. U., TISCHENDORF, L., WALZ, U. (2015): Understanding and quantifying landscape structure - A review on relevant process characteristics, data models and landscape metrics. Ecological Modelling, 295: 31-41.

LIANG, Y., HE, H. S., LEWIS, B. L. (2011): Responses of tree species to climate warming at different spatial scales. Chinese Geographical Science, 21(4): 427-436.

LIPSKÝ, Z. (1995): The changing face of the Czech rural landscape. Landscape and Urban Planning, 31: 39-45.

LONGLEY, P. A., GOODCHILD, M., MAGUIRE, D. J., RHIND, D. W. (2010): Geographical information systems and science ( $3^{\text {rd }}$ edition). Chichester, John Wiley \& Sons.

MACKOVČIN, P. (2009): Land use categorization based on topographic maps. Acta Pruhoniciana, 91: 5-14.

MACKOVČIN, P., BALATKA, B., DEMEK, J., KIRCHNER, K., SLAVÍK, P. (2009): Geomorfologické jednotky. Mapa měřítka 1 : 500,000. In: Hrnčiarová, T., Mackovčin, P., Zvara, I. et al.: Atlas krajiny České republiky. Oddíl 4. Přírodní krajina, Pododdíl 4.4. Reliéf, mapa č. 80, s. 122-123. Praha, MŽP ČR, Výzkumný ústav Silva Taroucy pro krajinu a okrasné zahradnictví, v. v. i.

MADĚRA, P., ÚRADNIČEK, L. (2000): Preliminary Study of Oak and Ash Growth Response on Changed Conditions of the Floodplain Forest Geobiocoene Hydrological 
Regime. In: Kulhavý, J., Hrib, M., Klimo, E. (2000): Management of Floodplain Forest in Southern Moravia (pp. 143-154). Židlochovice.

MADĚRA, P., ŘEPKA, R., ŠEBESTA, J., KOUTECKÝ, T., KLIMÁNEK, M. (2013): Vascular plant biodiversity of floodplain forest geobiocoenosis in lower Morava River basin (forest district Tvrdonice), Czech Republic. Journal of Landscape Ecology (Brno), 6(2): 34-64.

MACHAR, I. (2008): Changes in the fragmentation and ecological stability of the floodplain forest geobiocenosis of the Morava River floodplain in the course of the $20^{\text {th }}$ century. Journal of Landscape Ecology (Brno), 1: 38-48.

MACHAR, I. (2009): Conservation and Management of Floodplain Forests in the Protected Landscape Area Litovelske Pomoravi (Czech Republic) Introduction. In: Machar, I.: Conservation and Management of Floodplain Forests in the Protected Landscape Area Litovelske Pomoravi (Czech Republic) (pp. 7-108). Olomouc, Palacky University.

MACHAR, I., ANTONIN, V., CERMAK, P., HORCICKO, I., HRADILEK, Z., JANKOVSKY, L., JOHN, F., KOSTKAN, V., KULHAVY, J., KURFURST, P., LACINA, J., MACKA, Z., MERTA, L., MRKVA, R., SANKA, M., SIMON, J., VAGNER, A. (2009): History, Biodiversity, and Management of Floodplain Forest (Case Study of National Nature Reserve of Vrapac, Czech Republic). In: History, Biodiversity, and Management of floodplain Forest (Case Study of National Nature Reserve of Vrapac, Czech Republic) (pp. 1-140). Book Series: Univerzita Palackeho Monographie.

MACHAR, I. (2010): Attempt to summarize the problems: Is a sustainable management of floodplain forest geobiocoenoses possible? In: Machar, I. [ed.]: Biodiversity and Target Management of Floodplain Forests in the Morava River Basin (pp. 189-226). Olomouc, Palacky University.

MACHAR, I. (2012a): Changes in Ecological Stability and Biodiversity in a Floodplain Landscape. In: Machar, I. [ed.]: Applying Landscape Ecology in Conservation and Management of the Floodplain Forest (Czech Republic) (pp. 73-87). Olomouc, Palacky University.

MACHAR, I. (2012b): Protection of nature and landscapes in the Czech Republic. Selected current issues and possibilities of their solution. In: Machar, I., Drobilová, L. [eds.]: Ochrana prirody a krajiny v České Republice. Vol. I. and II. Olomouc, Palacky University.

MACHAR, I. (2013a): The Effect of Landscape Character Change on the Recreation Function of a Water Management Construction in the Landscape. Case study: Bata Canal, South Moravia (Czech Republic). In: Fialova, J., Kubickova, H. [eds.]: Public Recreation and Landscape Protection - with Man Hand in Hand (pp. 190-195). Conference Proceedings.

MACHAR, I. (2013b): Applying of Classification Systems of Floodplain Forest Ecosystems to Sustainable Forest Management Strategy in the Czech Republic. In: Geoconference on Water resources, Forest, Marine, and Ocean Ecosystems (pp. 765-770). Book Series: International Multidisciplinary Scientific GeoConference-SGEM, Albena Bulgaria.
MÁČKA, Z. (2009): Geology, Geomorphology and Human Impact over the Fluvial System. In: Machar, I. et al. [eds.]: History, Biodiversity, and Management of Floodplain Forest (Case study of National Nature reserve of Vrapac, Czech republic) (pp. 27-40). Book Series: Univerzita Palackeho Monographie.

McGARIGAL, K., CUSHMAN, S. A. (2005): The gradient concept of landscape structure. In: Wiens, J., Moss, M. [eds.]: Issues and Perspectives in Landscape Ecology (pp. 112-119). Cambridge University Press.

McGARIGAL, K., TAGIL, S., CUSHMAN, S. A. (2009): Surface metrics: an alternative to patch metrics for the quantification of landscape structure. Landscape Ecology, 24: 433-450.

NELSON, T., BOOTS, B. (2005): Identifying insect infestation hot spots: an approach using conditional spatial randomization. Journal of Geographical Systems, 7: 291-311.

OPRSAL, Z., KLADIVO, P., MACHAR, I. (2016): The Role of Selected Biophysical Factors in Long-term Land-use Change of Cultural Landscape. Applied Ecology and Environmental Research, 14 (2): 23-40.

OTÝPKOVÁ, Z., CHYTRÝ, M., TICHÝ, L., PECHANEC, V., JONGEPIER, J. W., HÁJEK, O. (2011): Floristic diversity patterns in the White Carpathians Biosphere. Biologia, 66(2): 266-274.

PAUKNEROVÁ, E., KUČERA, T. [eds.] (1997): Informační zdroje pro využití nástrojů GIS v ochraně přírody a krajiny. Praha, AOPK ČR.

PECHANEC, V., BURIAN, J., KILIANOVÁ, H., NĚMCOVÁ, Z. (2011a): Geospatial analysis of the spatial conflicts of flood hazard. Moravian Geographical Reports, 19(4): 11-19.

PECHANEC, V., BRUS, J., MIŘIJOVSKÝ, J. (2011b): Monitoring of snow risks by geo-sensors in urban areas. $11^{\text {th }}$ International Multidisciplinary Scientific GeoConference - SGEM 2011, (pp. 653-660). Albena, Bulgaria.

PECHANEC, V. (2012): GIS v ochraně přírody a krajiny. In: Machar, I. et al.: Ochrana př́rody a krajiny v České republice. Vybrané aktuální problémy a možnosti jejich řešení (pp. 738-748). Olomouc, Univerzita Palackého.

PECHANEC, V., VÁVRA, A., HOVORKOVÁ, M., BRUS, J., KILIANOVÁ, H. (2014): Analyses of moisture parameters and biomass of vegetation cover in southeast Moravia. International Journal of Remote Sensing, 35(3): 967-987.

PECHANEC, V., BRUS, J., KILIANOVÁ, H., MACHAR, I. (2015): Decision support tool for the evaluation of landscapes. Ecological Informatics, 30: 305-308.

RULF, J. (1994): Pravěké osídlení střední Evropy a niva. In: Rulf, J.: Archeologie a krajinná ekologie (pp. 55-64). Most, Nadace projekt Sever.

SALVATI, L., TOMBOLINI, I. (2013): Cropland vs Forests: Landscape Composition and Land-use Changes in PeriUrban Rome (1949-2008). WSEAS Transactions on Environment and Development, 9(4): 278-289.

SIMON J., MACHAR I., BUČEK A. (2014): Linking the historical research with the growth simulation model of hardwood floodplain forests. Polish Journal of Ecology, 62 (2): 273-288. 
SKALOŠ, J. et al. (2011): Using old military maps and orthophotograph maps to analyse long-term land cover changes - case study (Czech Republic) Applied Geography, 31: 426-438.

SKOKANOVÁ, H., HAVLÍČEK, M., BOROVEC, R., DEMEK, J., EREMIÁŠOVÁ, R., CHRUDINA, Z., MACKOVČIN, P., RYSKOVÁ, R., SLAVÍK, P., STRÁNSKÁ, T., SVOBODA, J. (2012): Development of land use and main land use change processes in the period 1836-2006: case study in the Czech Republic. Journal of Maps, 8(1): 88-96.

STUPARIU, M. S., PATRU-STUPARIU, I., CUCULICI, R. (2010): Geometric approaches to computation 3D-landscape metrics. Landscape Online, 24: 1-12.

ŠTĚRBA, O. [ed.] (1999): Obnova ekologického kontinua řeky Moravy. Olomouc, Palacký University in Olomouc.

TOCKNER, K., STANFORD, J.A. (2002). Riverine flood plains: present state and future trends. Environmental Conservation, 29(3): 308-330.

TOMLINSON, R. (2003): Thinking About GIS: geographic information system planning for managers. ESRI Press, Redlands, CA.
TRÉMOLIERES, M., SCHNITZLER, A. (2007): Floodplain Protection, Restoration, Management. Why and How. Paris, Lavoisier SAS.

VAN DER PLOEG, P.R., SCHWEIGERT, P. (2001): Elbe river flood peaks and postwar agricultural land use in East Germany. Naturwissenschaften, 88(12): 522-525.

VAN DOORN, A. M., BAKKER, M. M. (2007): The destination of arable land in a marginal agricultural landscape in South Portugal: an exploration of land use change determinants. Landscape Ecology, 22(7): 1073-1087.

WU, K., ZHANG, H. (2012): Land use dynamics, built-up land expansion patterns, and driving forces analysis of the fast-growing Hangzhou metropolitan area, eastern China (1978-2008). Applied Geography, 34: $137-145$.

ZHANG X., HU, H., XU, J., YIN, H. (2011) Coordination of urbanization and water ecological environment in Shayinghe river basin, China. Chinese Geographical Science, 21(4): 476-495.

Please cite this article as:

KILIANOVÁ, H., PECHANEC, V., BRUS, J., KIRCHNER, K., MACHAR, I. (2017): Analysis of the development of land use in the Morava River floodplain, with special emphasis on the landscape matrix. Moravian Geographical Reports, 25(1): 46-59. Doi: 10.1515/ mgr-2017-0005. 